\title{
Examining the Equilibrium Relationships between Foreign Direct Investment Inflows and Employment in Manufacturing and Services Sectors: Evidence from Malaysia
}

\author{
Hussain Ali Bekhet*, Mohamed Ibrahim Mugableh \\ University Tenaga Nasional (UNITEN), Selangor-Malaysia \\ *profhussain@uniten.edu.my
}

\begin{abstract}
The current paper examines the long-run and short-run equilibrium relationships between FDI inflows and employment in Malaysian manufacturing and services sectors using ARDL approach for the 19722011 period. It employs ADF and PP tests to detect the stationary levels of above variables. Also, it utilizes the bounds F-statistics test to identify the co-integration among variables. Results of ARDL approach indicate the presence of significant long-run and short-run equilibrium relationships between FDI inflows and employment in manufacturing and services sectors. The paper's findings are of particular interest and importance to Malaysian policy makers towards increasing FDI inflows and employment in manufacturing and services sectors.
\end{abstract}

Keywords: FDI; Employment; Manufacturing; Services; Malaysia

\section{Introduction}

Foreign direct investment (FDI) is an important source of capital in host countries that complements domestic private investment, creates employment, enhances technology transfer and boosts overall economic growth (Chowdhury and Mavrotas, 2005). Also, FDI is one of the most major factors leading to the globalization of international economy (Kok and Ersoy, 2009). However, several studies established the relationships between FDI and its determinants (See, for example, Vita and Kyaw, 2007; Andraz and Rodrigues, 2008; Ang, 2008).The results showed that FDI enhanced economic growth and significantly influenced by various determinants. On the other hand, there are few studies conducted to investigate the influences of FDI inflows on employment in economic sectors (Mickiewicz et al., 2000; McDonald et el., 2002; Jenkins, 2006; Tang and Gyasi, 2012). The results revealed that FDI inflows increased economic growth and boosted employment in various economic sectors. The current paper extends the existing literature by analyzing the long-run and short-run equilibrium relationships between FDI inflows and employment in manufacturing and services sectors. However, the significant of this paper that there is no authoritative work analyzed the long-run and short-run equilibrium relationships between FDI inflows and employment in manufacturing and services sectors using autoregressive distributed lag (ARDL) approach and Malaysian annual time-series data for the 1972-2011 period. The paper plan is organized as follows: section 2 provides an overview of FDI and Malaysian economy. Section 3 presents literature review. Data and methodology specification are discussed in section 4 . Section 5 reports results analyses. Policy implications are drawn in section 6. Finally, conclusions, future research and limitation are presented in section 7.

Overview of FDI and Malaysian Economy: Since the independence in 1957, Malaysia has taken advantages of tangible assets such as natural recourses and abundant labor. Also, it takes intangible assets such as trade status, macroeconomic stability, education system and infrastructure (Trade Chakra, 2012). However, these tangible and intangible assets have been the main policy of Malaysian government to bring in FDI as a key of economic growth strategy to acquire foreign technology, capital and skills. Malaysia has been one of the largest South-East Asian countries in attracting FDI. Figure 1 shows that Malaysian FDI inflows recorded annual growth rate of $8.3 \%$ for the $1972-2011$ period. 
Figure 1: Malaysian FDI Inflows for the 1972-2011 period.

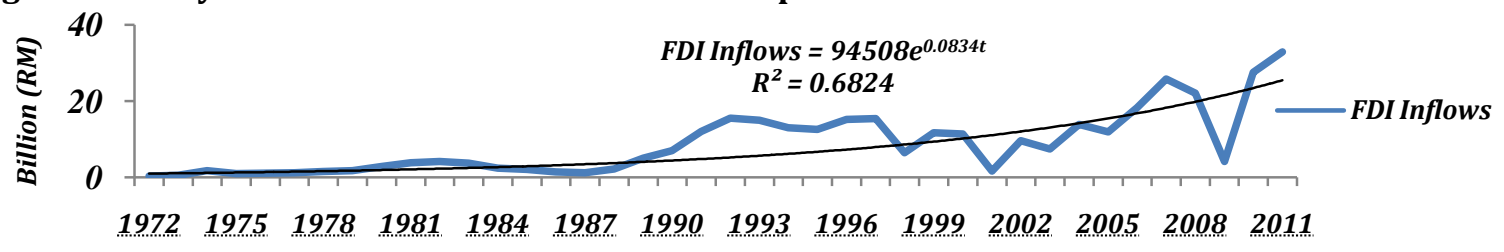

Source: World Development Indicators Database, http://data.worldbank.org/country/malaysia.

The Malaysian FDI inflows started in 1972 amounted RM342 million and remained increasing due to the new economic policy [NEP] that started in 1971 (Athukorala, 2010). The goal of NEP was to establish new public corporations to enhance manufacturing sectors and exports in Malaysia. On November 1980, the NEP entered a new phase and the Malaysian government announced to establish the heavy industries corporations of Malaysian (HICOM) projects in many areas. These areas are; petrochemicals, iron, steel, paper products, cement, machinery and equipment, general engineering, building materials, transport equipment and energy projects including petronas's production (Athukorala, 2010). However, FDI flows into Malaysia increased significantly in 1981 valued RM3.794 billion as a result of HICOM projects establishment (Athukorala, 2010). As a result of high levels of FDI inflows, Malaysia has been one of the best performers among largest SouthEast Asian countries. Figure 2 reveals that Malaysian economic growth rate, real gross domestic product (RGDP), achieved $5.9 \%$ for the $1980-2011$ period.

Figure 2: Real Gross Domestic Product for the 1980-2011 period.

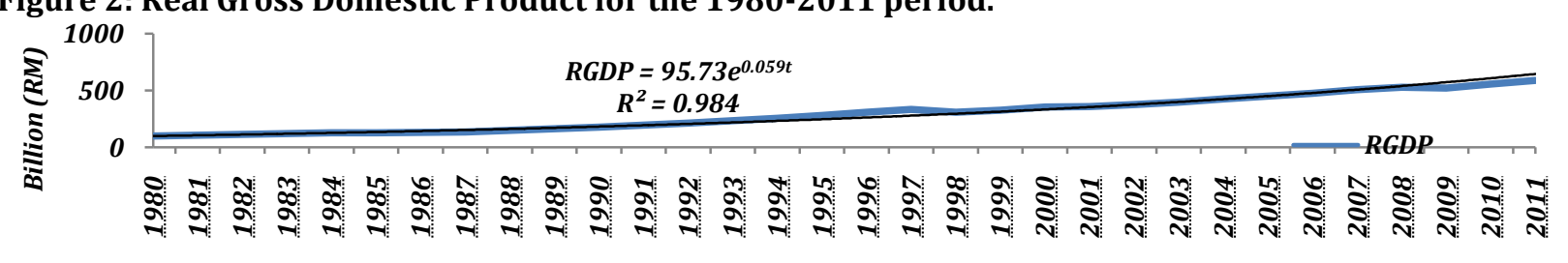

Source: International Monetary Fund, http://www.imf.org/external/data.htm.

Inflation recorded an inverse growth rate of $-1 \%$ for the 1970-2011 period (See, Figure 3).

Figure 3: Inflation Rate for the 1970-2011 period.

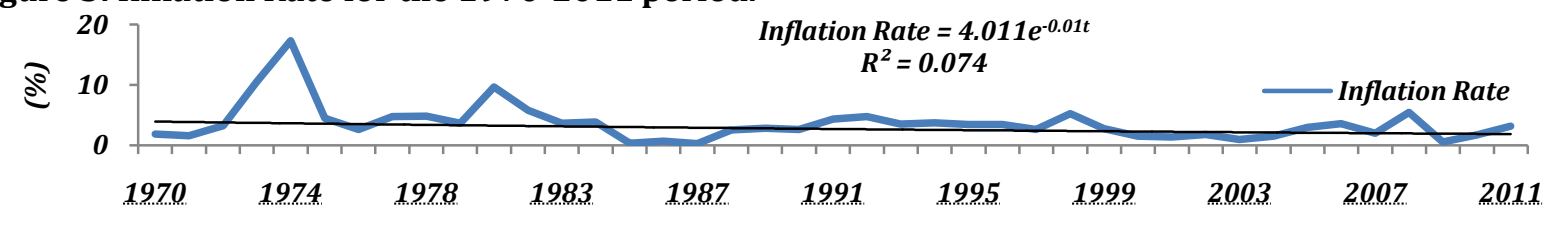

Source: World Development Indicators Database, http://data.worldbank.org/country/malaysia.

However, due to HICOM projects establishment and the high levels of FDI flows into Malaysia, unemployment rates decreased dramatically and achieved an inverse growth rate of $-3 \%$ for the 1985-2011 period (See, Figure 4).

Figure 4: Unemployment Rate for the 1985-2011 period.

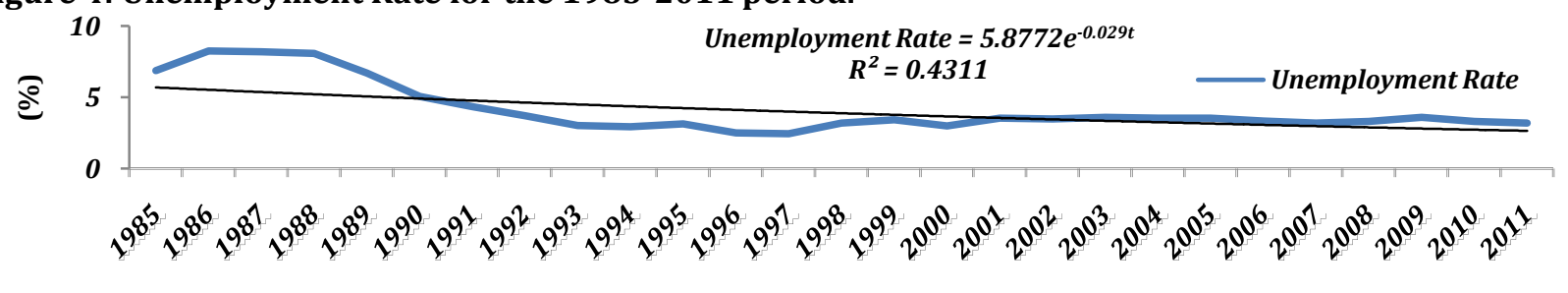

Source: International Monetary Fund, http://www.imf.org/external/data.htm. 


\section{Literature Review}

Economists literatures have been widely enriched by past studies examined the relationships between inward FDI and its determinants using time-series models. Applying vector autoregressive Model and quarterly time-series data for the 1976-2001 period, Vita and Kyaw (2007) examined the influences of domestic and foreign factors namely; foreign GDP, foreign interest rate, domestic GDP and domestic broad money supply on FDI and portfolio flows into Brazil, Mexico, the Philippine and South Korea. The results showed that domestic and foreign factors were significantly influenced the variations of FDI and portfolio flows into Brazil, Mexico, the Philippine and South Korea. Andraz and Rodrigues (2008) applied vector error correction Model and annual time-series data for the 1977-2004 period to investigate the co-integration between inward FDI and exports in Portugal. The results revealed that exports were shared long-run relationship with inward FDI. Also, Ang (2008) employed generalized autoregressive conditional heteroscedasticity Model to examine the determinants of FDI flows into Malaysia using annual time-series data for the 1960-2005 period. Specifically, he used financial development measured by the ratio of private credit to GDP, annual growth rate of GDP, infrastructure development measured by the total spending of Malaysian government on transport and communication, economic openness, real effective exchange rate and tax rate as determinants of FDI flows into Malaysia. The results showed that above determinants significantly influenced FDI flows into Malaysia.

On the other hand, notable studies recognized that inward FDI enhanced economic growth and increased employment in economic sectors. With the reference to emerging European economies namely; Czech Republic, Slovakia, Estonia and Hungary, Mickiewicz et al. (2000) investigated the role of inward FDI on employment preservation/creation using disaggregated data of FDI flows in manufacturing sector for the 1995-1997 period. The findings showed that the role of inward FDI on employment creation/preservation had been the most successful in Estonian and Hungarian economies. McDonald et el. (2002) examined the impact of Germanic FDI inflows on the employment levels in European countries. The results revealed that Germanic FDI inflows increased economic growth rate and boosted employment in various economic sectors in European countries. However, Jenkins (2006) explored the impact of inward FDI on employment in Vietnamese economic sectors. The results showed that inward FDI increased employment in Vietnamese economic sectors through the creation of Greenfield projects. Tang and Gyasi (2012) debated the impact of Chinese FDI flows into Ghanaian manufacturing, building \& construction and general economic sectors for the 2006-2010 period. They noticed that 91 percent of the total employment in Ghanaian economic sectors came from Chinese FDI. Based on above discussions of literature review, the following hypotheses could be formulated as follows:

$H_{1}$ : There are significant long-run equilibrium relationships among inward FDI, and employment in manufacturing, and in services sectors.

$\mathrm{H}_{2}$ : There are significant short-run equilibrium relationships among inward FDI, and employment in manufacturing, and in services sectors.

\section{Methodology}

Data Sources and Descriptions: The present paper uses annual time-series data of FDI inflows and employment in manufacturing (EM) and in services (ES) sectors covering the 1972-2011 period. However, data on EM and ES were collected from the Malaysian department of statistics (www.statistics.gov.my).While, data on FDI inflows (RM billion) was obtained from the World Bank Development Indicators Database (http://data.worldbankorg/country/malaysia). In the current study, the transformations into natural logarithmic forms [LFDI, LEM and LES] were used to standardize time-series data (Montgomery et al., 2008).

Methodology Specification: The current paper attempts to examine the long-run and short-run equilibrium relationships among Malaysian LFDI inflows, LEM and LES by relaying on Equation (1).

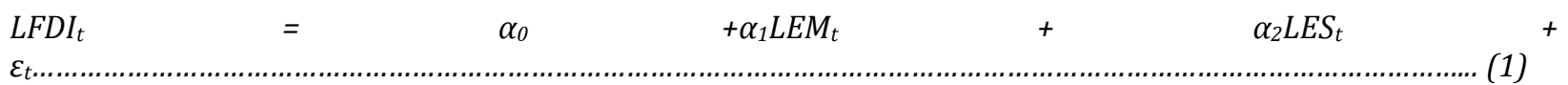


Where $\alpha_{0}$ denotes the intercept term; $\alpha_{1}$ and $\alpha_{2}$ represent the coefficients of explanatory variables; $\varepsilon_{\mathrm{t}}$ denotes the error term. Equation 1 can be augmented by introducing the error correction terms of ARDL Approach (See, Equations 2-4).

$$
\begin{aligned}
& \Delta L F D I_{t}=\alpha_{1}+\delta_{1} E C M_{t-1}+\lambda_{11} L F D I_{t-1}+\lambda_{12} L E M_{t-1}+\lambda_{13} L E S_{t-1}+\sum_{k=1}^{2} \Gamma_{11} \Delta L F D I_{t-k}+\sum_{k=1}^{2} \Gamma_{12} \Delta L E M_{t-k}+\sum_{k=1}^{2} \Gamma_{13} \Delta L E S_{t-k}+
\end{aligned}
$$

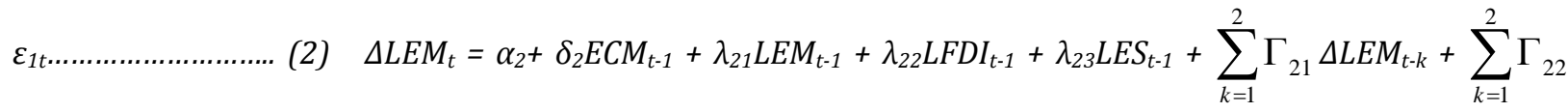

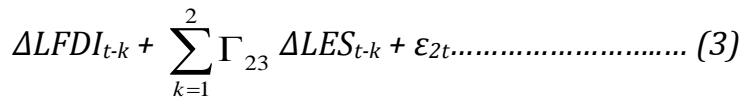

$\Delta L E S_{t}=\alpha_{3}+\delta_{3} E C M_{t-1}+\lambda_{31} L E S_{t-1}+\lambda_{32} L F D I_{t-1}+\lambda_{33} L E M_{t-1}+\sum_{k=1}^{2} \Gamma_{31} \Delta L E S_{t-k}+\sum_{k=1}^{2} \Gamma_{32} \Delta L F D I_{t-k}+\sum_{k=1}^{2} \Gamma_{33} \Delta L E M_{t-k}+$

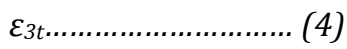

Where $\lambda_{\mathrm{ij}}(i, j=1, \ldots .3)$ represents the long-run coefficients of the one lagged variables; $\Gamma_{\mathrm{ij}}(i, j=1, \ldots . .3)$ denotes the short-run coefficients of the variables differences; $\delta_{\mathrm{i}}(i=1, \ldots 3)$ represents the coefficients of error correction terms; and $\left(\mathrm{ECM}_{\mathrm{t}-1}\right)$ 's indicate the error correction terms that are used to link the long-run with the short-run equilibrium; $\varepsilon_{\mathrm{it}}(\mathrm{i}=1, \ldots 3)$ represents error terms. The present paper uses ARDL approach to examine the longrun and short-run equilibrium relationships among Malaysian LFDI inflows, LEM and LES. Specifically, it starts by testing the variables stationarity levels using augmented Dickey-Fuller (ADF) and Phillips and Perron (PP) tests. Then, the paper utilizes the bounds F-statistics to test the co-integrating relationships among variables. Finally, we use the results of stationarity and co-integration to analyze the long-run and short-run equilibrium relationships.

\section{Results and Analyses}

Stationarity Tests: Table 1 reports the stationarity results of ADF and PP tests which are carried on the logarithms of the variables in levels and using the deterministic components of intercept and trend. However, the results show that all variables are stationary at $I(1)$ and $1 \%$ significance level. Therefore, it is reasonably to apply ARDL approach.

Table 1: Stationarity Tests Results.

\begin{tabular}{|c|c|c|c|c|c|c|c|c|c|}
\hline \multirow[b]{2}{*}{ Stage } & \multirow[b]{2}{*}{ Variables } & \multirow{2}{*}{$\begin{array}{l}\text { ADF } \\
\text { Intercept } \\
\text { Trend }\end{array}$} & \multirow[b]{2}{*}{ and } & \multicolumn{2}{|c|}{ Critical Values } & \multirow{2}{*}{$\begin{array}{l}\text { PP } \\
\text { Intercept } \\
\text { Trend }\end{array}$} & \multirow[b]{2}{*}{ and } & \multicolumn{2}{|c|}{ Critical Values } \\
\hline & & & & $1 \%$ & $5 \%$ & & & $1 \%$ & $5 \%$ \\
\hline \multirow{3}{*}{$I(0)$} & LFDI $_{t}$ & $-3.80^{* *}$ & & -4.21 & -3.53 & $-3.70^{* *}$ & & -4.19 & -3.48 \\
\hline & $\mathrm{LEM}_{\mathrm{t}}$ & -2.37 & & -4.16 & -3.46 & -2.38 & & -4.13 & -3.36 \\
\hline & $\mathrm{LES}_{\mathrm{t}}$ & $-4.89^{*}$ & & -4.17 & -3.52 & $-4.83^{*}$ & & -4.20 & -3.39 \\
\hline \multirow{3}{*}{$I(1)$} & $\Delta \mathrm{LFDI}_{\mathrm{t}}$ & $-6.86^{*}$ & & -4.23 & -3.51 & $-8.75^{*}$ & & -4.18 & -3.46 \\
\hline & $\Delta \mathrm{LEM}_{\mathrm{t}}$ & $-7.84^{*}$ & & -4.21 & -3.54 & $-7.73^{*}$ & & -4.22 & -3.53 \\
\hline & $\Delta \mathrm{LES}_{\mathrm{t}}$ & $-6.45^{*}$ & & -4.23 & -3.56 & $-11.43^{*}$ & & -4.26 & -3.47 \\
\hline
\end{tabular}

Notes: ${ }^{*, * *}$ denote the significance at $1 \%$ and $5 \%$ levels respectively.

Source: Output of Eviews package, version 7.

Co-integration Test: The current paper employs the bounds F-statistics test as suggested by Pesaran et al. (2001) to test $H_{0}$ of no co-integration among the variables. However, the long-run coefficients of the one lagged variables (Equations 2-4) are equal zero, i.e., $H_{0}: \lambda_{i j}=0$ against $H_{1}: \lambda_{i j} \neq 0$. The computed F-statistics value is compared with critical values tabulated in statistical tables at $I(1)$ and $I(0)$ [Pesaran et al., 2001]. If the computed F-statistic is greater than $I(1)$, then, $H_{0}$ of no co-integration is definitely rejected. Conversely, if the computed F-statistic is less than $I(0)$, then, $H_{0}$ is accepted (Pesaran et al., 2001). If the computed F-statistic falls between $I(1)$ and $I(0)$, then, the decision becomes inconclusive (Pesaran et al., 2001). Table 2 provides results of F-statistics computed and critical values. 
Table 2: Co-integration Test Results.

\begin{tabular}{lllll}
\hline \multirow{2}{*}{ Models } & \multirow{2}{*}{ Computed F-statistics } & $\begin{array}{l}\text { F-statistics Critical Values } \\
\text { Significance Levels }\end{array}$ & I(0) & I(1) \\
\hline LFDI $_{\mathrm{t}}$ & $4.88^{* *}$ & $10 \%$ & 2.37 & 3.20 \\
$\mathrm{LEM}_{\mathrm{t}}$ & $3.77^{* *}$ & $5 \%$ & 2.79 & 3.67 \\
$\mathrm{LES}_{\mathrm{t}}$ & $3.24^{*}$ & Notes: $:^{* *, *}$ denote the significance at $10 \%$ and $5 \%$ levels respectively. \\
\hline
\end{tabular}

Source: Output of Micro-fit package, version 4.

Table 2 illustrates that $H_{0}$ of no co-integration among variables in $\mathrm{LFDI}_{\mathrm{t}}$ and $\mathrm{LEM}_{\mathrm{t}}$ models are rejected at $10 \%$ significance level. Moreover, we reject $H_{0}$ of no co-integration among variables in LES $_{\mathrm{t}}$ model, since the computed F-statistics (3.24) falls between $I(1)$ and $I(0)$. Therefore, all the variables in $L_{F D I}, L^{2} M_{t}$ and $L_{E S}$ models are co-integrated.

Long-run and Short-run Relationship Analysis: The present paper analyzes the long-run and short-run equilibrium relationships among Malaysian LFDI inflows, LEM and LES. However, after conducting the bounds F-statistic test; we conclude that all the variables in all models are co-integrated. Equations(5-7) demonstrate the estimation of long-run coefficients.

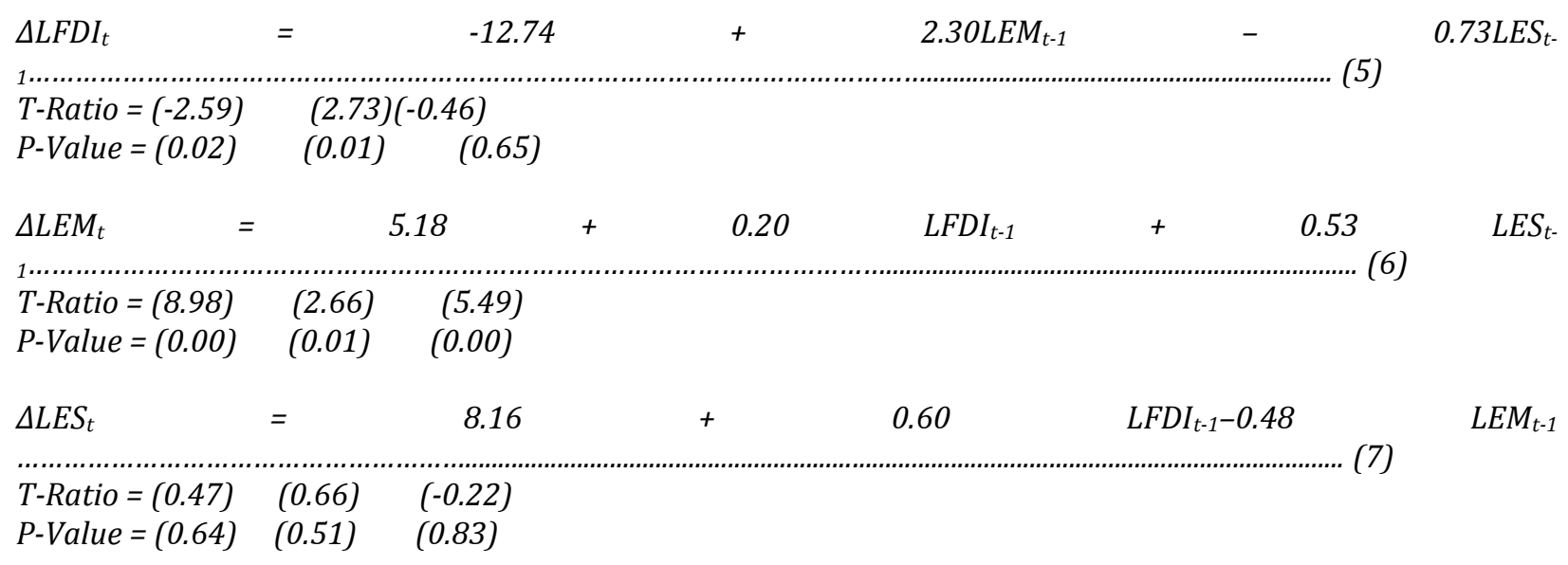

At $1 \%$ significance level, $\mathrm{LEM}_{\mathrm{t}-1}$ is positively associated with $\Delta \mathrm{LFDI}_{\mathrm{t}}$ model, Equation 5, while, Equation 6 , $\mathrm{LFDI}_{\mathrm{t}-1}$ and $\mathrm{LES}_{\mathrm{t}-1}$ are positively related to $\Delta \mathrm{LEM}_{\mathrm{t}}$ model.

Therefore, the next step is to examine the short-run and error correction terms. However, Equations (8-10) provide the estimations of short-run and error correction terms coefficients.

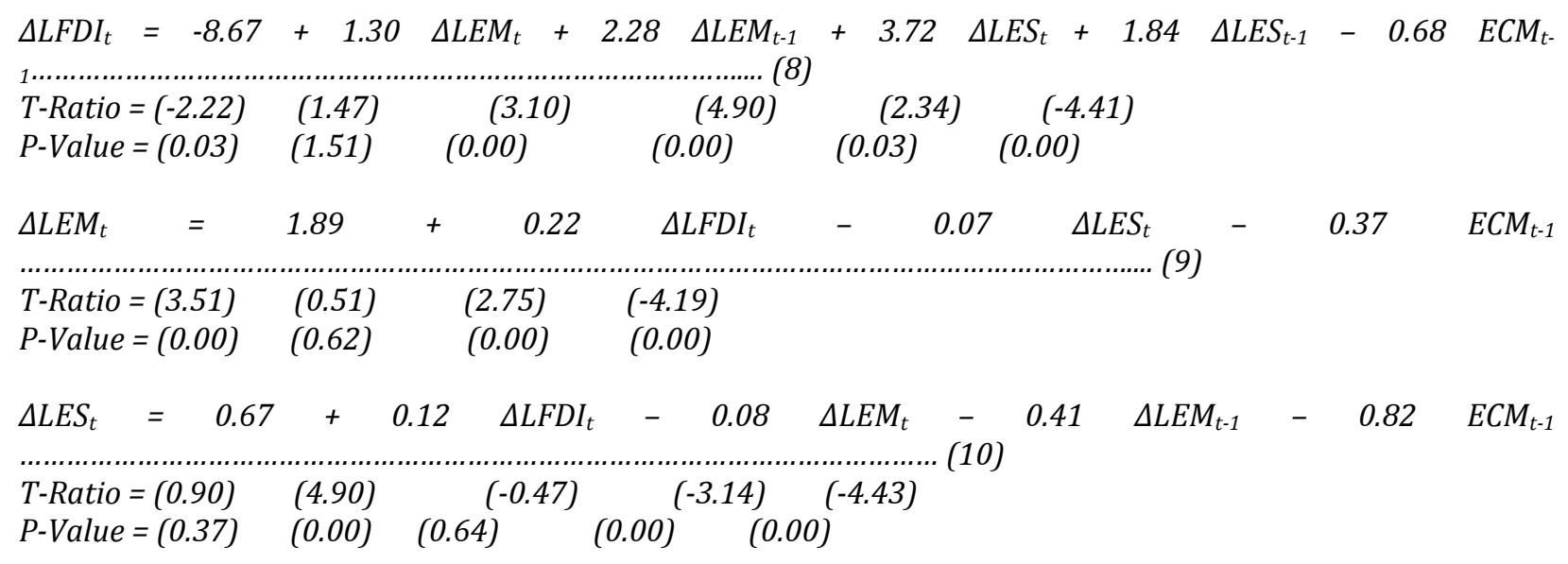


Equation 8 shows that the lagged values of $\Delta \mathrm{LEM}_{\mathrm{t}}$ and $\Delta \mathrm{LES}_{\mathrm{t}}$ are positively associated with $\Delta \mathrm{LFDI}_{\mathrm{t}}$ model at $1 \%$ and $5 \%$ significance levels. Moreover, Equation $9, \Delta \mathrm{LES}_{\mathrm{t}}$ is negatively related to $\Delta \mathrm{LEM}_{\mathrm{t}}$ model at $1 \%$ significance level. However, Equation $10, \Delta \mathrm{LFDI}_{\mathrm{t}}$ is positively associated with $\Delta \mathrm{LES}_{\mathrm{t}}$ model and $\Delta \mathrm{LEM}_{\mathrm{t}-1}$ is negatively related to $\Delta \mathrm{LES}_{\mathrm{t}}$ model at $1 \%$ significance level. Based on Equations[8-10], $\left(\mathrm{ECM}_{\mathrm{t}-1}\right)^{\prime}$ 's coefficients in all models are statistically significant with appropriate signs. The highly significant of $\mathrm{ECM}_{\mathrm{t}-1}$ coefficient implies a quite speed of reaching the long-run equilibrium. For instance, $\Delta \mathrm{LES}_{\mathrm{t}}$ model, Equation 10,records the highest $\mathrm{ECM}_{\mathrm{t}-1}$ coefficient in absolute value among other models, suggesting that $82 \%$ of any previous disequilibrium in long-run would be shortly corrected back in the current year. However, $\Delta \mathrm{LEM}_{\mathrm{t}}$ model, Equation 9, records the lowest $\mathrm{ECM}_{\mathrm{t}-1}$ coefficient in absolute value, implying a low speed toward the long-run equilibrium.

Policy Implications: The relationships between FDI inflows and economic growth are two ways directions. FDI inflows could enhance economic growth and similarly economic growth could attract FDI inflows. Metwally (2004) proposed that the economies that achieve economic growth succeed in attracting FDI. Conversely, he argued that FDI inflows enhance economic growth through the expansion of economic productive capacity and reduces the needs for borrowings that increase technological and managerial skills. Also, FDI inflows boost economic growth through the creation of employment. The findings of this paper are consistence with findings of McDonald et el. (2002) study that revealed, FDI inflows increased employment in European economic sectors. Therefore, Malaysian policy makers should be aware to the influences of FDI inflows on employment in Malaysian economic sectors. The benefits of FDI inflows in host country not only create jobs and increase employment in economic sectors, but also, increase capital, production and management techniques. Furthermore, FDI inflows through multinationals corporations upgrade the technology that is used in economic sectors which increases production's quality and the competitiveness in domestic and international markets.

\section{Conclusion, Future Research and Limitations}

Previous studies established that FDI inflows enhanced economic growth and increased employment in economic sectors. This paper contributes to the existing literature by examining the long-run and short-run equilibrium relationships among FDI inflows, EM and ES in Malaysia using ARDL Approach. The results of $\mathrm{ADF}$ and PP tests suggest that all variables are stationary at I(1) and 1\% significance level. The findings of the bounds F-statistics test reveal the existence of co-integration among variables. Besides, EM and ES are positively associated with FDI inflows in the long-run and short-run. In fact, future research could broaden this study by including more economic sectors such as agriculture, forestry and fishing sector; mining and quarrying sector; and construction sector. From statistical perspective, the main limitation of this study is the small sample size of 40 observations which has a limiting factor, since the number of lags that use, consumes the number of observations and leads to specification errors in the analysis (Gujarati and Porter, 2008).

\section{References}

Andraz, J. M. \& Rodrigues, P. M. M. (2008). What causes economic growth in Portugal: Exports or inward FDI? Journal of Economic Studies, 37(3), 267-287.

Ang, J. B. (2008). Determinants of FDI in Malaysia. Journal of Policy Modeling, 30, 185-189.

Athukorala, P. C. (2010). Malaysian economy in three crises. Working Papers in Trade and Development. The Australian National University, http://www.crawford.anu.edu.au/acde/publications/publish/papers/wp2010/wp_econ_2010_12.p df.

Chowdhury, A. \& Mavrotas, G. (2005). FDI and growth: A causal relationship. United Nations University, world institute for development economic research, working paper no. 2005/25, http://www.wider.unu.edu/stc/repec/pdfs/rp2005/rp2005-25.pdf.

Dickey, D. A. \& Fuller, W. A. (1979). Distribution of the estimators for auto-regression time series with a unit root. Journal of the American Statistical Association, 10, 291-321.

Gujarati, D. \& Porter, D. (2008). Basic econometrics, (5thed), the McGraw-Hill companies, New York, USA.

Jenkins, R. (2006). Globalization, FDI and employment in Viet Nam. Transnational corporations, 15(1), 115142. 
Kok, R. \& Ersoy, B. A. (2009). Analyses of FDI determinants in developing countries. International Journal of Social Economics, 36(1/2), 105-123.

McDonald, F., Heinz, J. \& Arn- Hiese, T. (2002). FDI and employment in host regions. European Business Review, 14(1), 40-50.

Metwally, M. M. (2004). Impact of EU FDI on economic growth in Middle Eastern countries. European Business Review, 16(4), 381-389.

Mickiewicz, T., Radosevic, S. \& Varblane, U. (2000). The value diversity: FDI and employment in central Europe during economic recovery. Sussex European Institute, University of Sussex, working paper no. 2005/00, available on line at: http://www.inti.gov.ar/cadenasdevalor/documentacion/WP5.pdf.

Montgomery, D. S., Jennings, C. L. \& Kulahci, M. (2008). Introduction to time series analysis and forecasting, (1sted), John Wiley \& Sons. Inc, Canada.

Pesaran, M. H., Shin, Y. \& Smith, R.J. (2001). Bounds testing approach to the analysis of level relationships. Journal of Applied Econometrics, 16, 289-326.

Phillips, P. C. B. \& Perron, P. (1988). Testing for a unit root in time series regression. Biometrika, 75, 335-46.

Tang, D. \& Gyasi, K. B. (2012). China-Africa trade policies: The impact of China's FDI flow on employment of Ghana. Energy Procedia, 16, 553-557.

Trade Chakra. (2012), available online at: http://www.tradechakra.com/economy/malaysia/fdi-in-malaysia198.php.

Vita, G. D. \& Kyaw, K. S. (2007). Determinants of capital flows to developing countries: A structural VAR analysis. Journal of Economic Studies, 35(4), 304-322. 